\title{
Water Flooding
}

By

Tomoya TAKEI

\begin{abstract}
In this paper the outline of both the basic experiment of water flooding and the actual application of water flooding to oil fields in Japan is explained.
\end{abstract}

\section{1. 緒言}

觶徣、回収量の增加をはかるため，2次回取法が研究 され，とくに水攻法が活潑に油田に対して奏施された。

来才゙, 水攻法の基本的現場寒験として，東山油田桂沢 坑道比圧大孔を開整し, 昭和 24 年 (1949) 11 月に水の

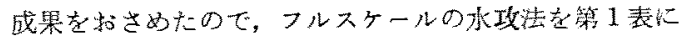
示した 13 地区で実施した。

全帝不の水攻法の経過は，第1图に示した通りであ

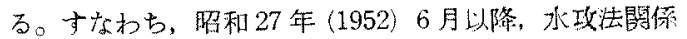

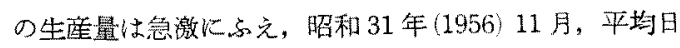

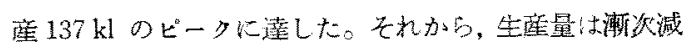

第工表水攻法実旅摡要

(昭和 34 年 9 号来)

\begin{tabular}{|c|c|c|c|c|c|c|c|c|c|c|c|c|c|}
\hline \multirow{2}{*}{ 油田， } & & \multirow{2}{*}{\multicolumn{3}{|c|}{ 地 区 名 }} & \multirow{2}{*}{ 臤入開始日 } & \multirow{2}{*}{\multicolumn{2}{|c|}{ 压入井数 }} & \multirow{2}{*}{ 採油 } & \multirow{2}{*}{ 新数 } & 註 & (k) & \multirow{2}{*}{ 備 } & \multirow{2}{*}{ 然 } \\
\hline & & & & & & & & & & 压入輩 & 增 油鳘 & & \\
\hline \multirow[b]{4}{*}{ 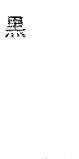 } & $川$ & 深 & & 層 & 30.10 .1 & 3 & (0) & 9 & (0) & 41,17786 & \multirow{6}{*}{$\begin{array}{r}1,17438 \\
12,311 \\
32,740 \\
28,93584\end{array}$} & \multirow[t]{5}{*}{32.} & \multirow{5}{*}{ 6来中止 } \\
\hline & & 高 & 野 I & $\mathrm{BL}$ & 32. 4. 1 & 4 & (3) & 15 & (12) & $61,612,68$ & & & \\
\hline & & & 權 & & 30. 4. 1 & 10 & (9) & 41 & (30) & 369,92536 & & & \\
\hline & & 雄 & 物川 IV & $\mathrm{VBL}$ & 29. 1. 1 & 8 & (8) & 17 & (14) & 384,08144 & & & \\
\hline \multirow{3}{*}{\multicolumn{2}{|c|}{ 八橋 III 層 }} & & III & & 26. 3. 12 & 8 & ( 7$)$ & 15 & (11) & 550,58604 & & & \\
\hline & & & IIIs & & 30. 9.1 & 2 & $(0)$ & 3 & $(0)$ & 46,23496 & & \multirow{2}{*}{\multicolumn{2}{|c|}{ 33.12末中止 }} \\
\hline & & & I & " & $29.3,10$ & 7 & (2) & 11 & $(10)$ & 166,25993 & 2,12363 & & \\
\hline 八橋 IV & 周 & パ & $1=9$ & 1 & 32. 4. 1 & 2 & (0) & 5 & $(0)$ & 18.44388 & \multirow{6}{*}{$\begin{array}{r}2,213 \\
5,67878 \\
2,40588 \\
69777\end{array}$} & \multirow[t]{5}{*}{33.} & \multirow[t]{5}{*}{ 8本中止 } \\
\hline 院 & 内 & 上 & 小国 II & I 層 & 29. 2. 10 & 6 & (4) & 8 & (5) & 67,64015 & & & \\
\hline 新 & 津 & 小 & 므 IIA & 層 & 29. 5.12 & 10 & (10) & 33 & 31 & $281,348,82$ & & & \\
\hline \multirow{2}{*}{ 東 } & \multirow{3}{*}{ 山 } & & B & 缕 & 29.1 .11 & 5 & $(0)$ & 24 & (12) & $58,399 \mid 38$ & & & \\
\hline & & & C & 賏 & 30. 4. 20 & 12 & (0) & 56 & (41) & $79,797 \mid 07$ & & & \\
\hline 西 & & & C & 䚑 & 30.3 .15 & 5 & (0) & 11 & $(0)$ & $8,117|52|$ & & \multicolumn{2}{|l|}{32.} \\
\hline
\end{tabular}

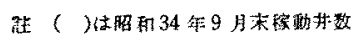

压入を開绐した。その結果が良好のため, 油田実験と

して昭和 26 年 3 月，八橋 III 層雄物川 III ブロックの OC 33を改修し，压入并代什上げ，水の生入を祭始し，
退し，昭和 34 年9月の日座量は $71 \mathrm{kl}$ でるる

現在末での水攻法沉よる累計增油䁷は $88,300 \mathrm{kl} て$ ， その5ち $77,300 \mathrm{kl}$ は公橋油由に扣ける水攻法增であ る。 
第2表水攻法害施地区油層の形㬅

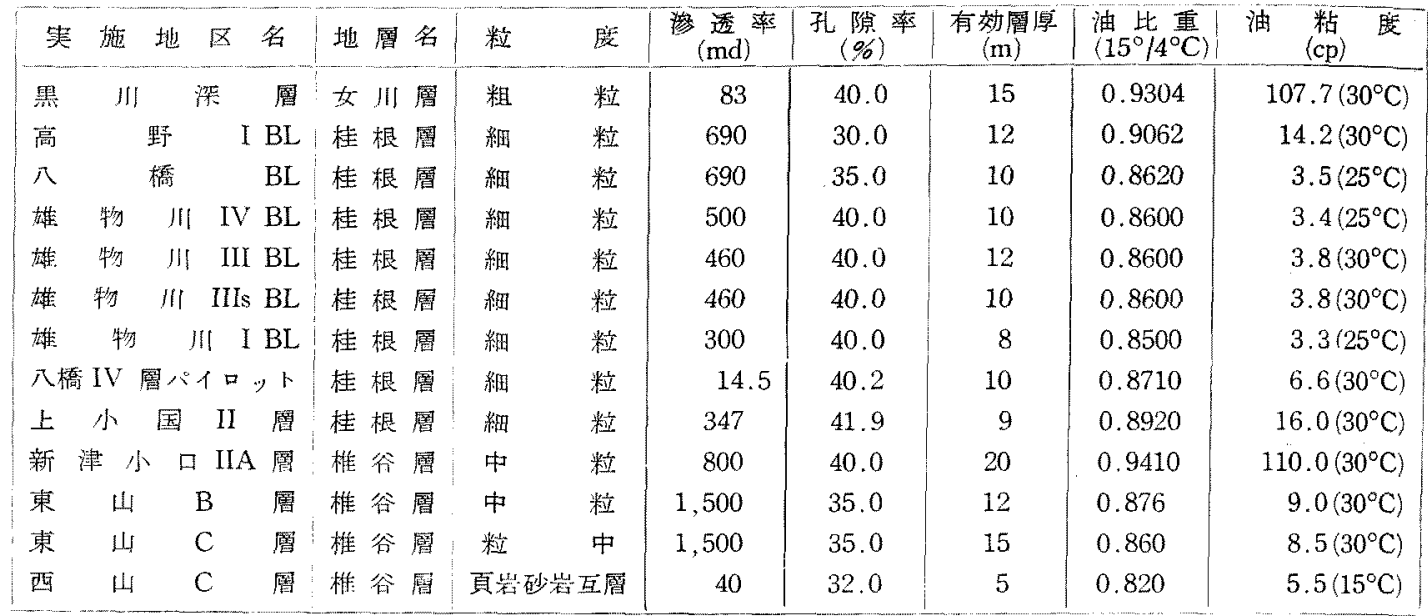

第 1 図全帝石水攻法程過

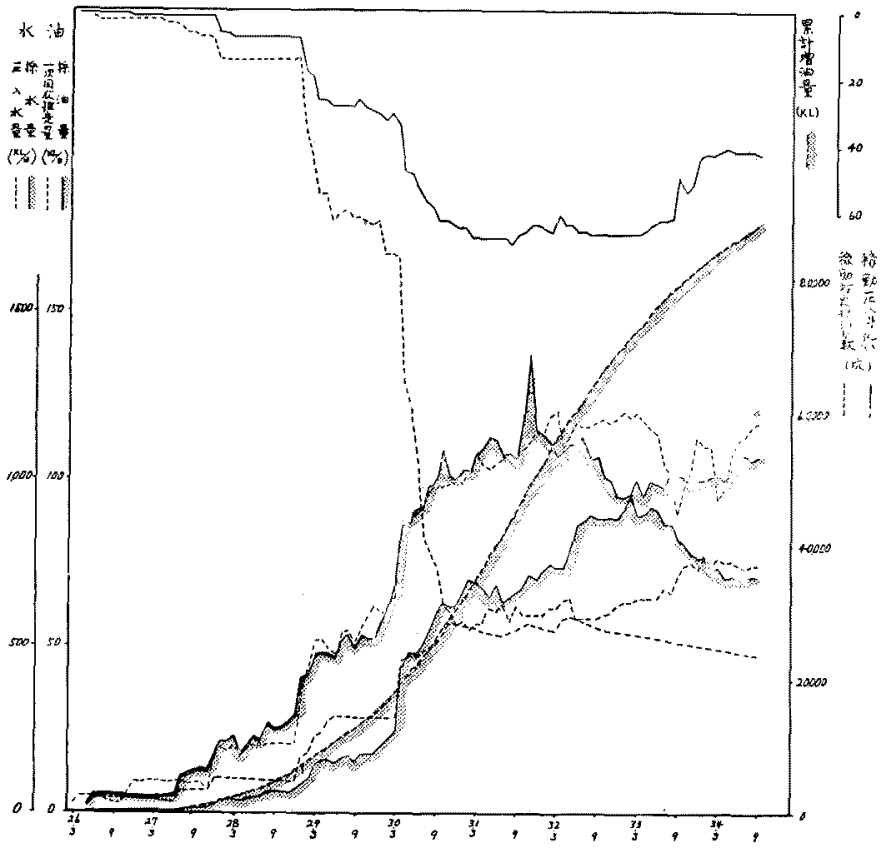

外に設けられ，これょり鉄箭にて水を導 き, 忘低差に上る王切で T. 50 の滐度 36〜 40 m の籄所方以油層中に水を田入 し，対象採油孔である T. 49，T. 51 で 㧮油している。

昭和 24 年(1949) 11 月 25 日 T. 50人

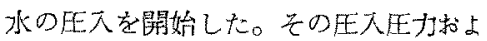
び承基は次の通りである。

[第1回目の実䮄の記録]

\begin{tabular}{|c|c|c|c|c|}
\hline 月 & 日 & 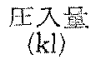 & 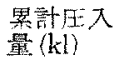 & $\underset{(\mathrm{ksc})}{\stackrel{x}{\mathrm{I}} \text { 力 }}$ \\
\hline 月 25 & 日 & 4.10 & 4.10 & 6.5 \\
\hline 26 & 日 & 3.75 & 7.85 & 6.7 \\
\hline 27 & 日 & 5.20 & 13.05 & 6.6 \\
\hline 28 & 日 & 5.05 & 18.10 & 6.8 \\
\hline 29 & 日 & 3.72 & 21.82 & 7.0 \\
\hline 30 & 日 & 3.50 & 25.32 & 7.2 \\
\hline 1 & 日 & 3.46 & 28.78 & 7.2 \\
\hline 2 & 日 & 3.30 & 32.08 & 7.2 \\
\hline 3 & 日 & 3.07 & 35.15 & 7.2 \\
\hline 4 & 日 & 2.86 & 38.01 & 7.0 \\
\hline 5 & 日 & 2.45 & 40.46 & 7.0 \\
\hline 6 & 日 & 2.35 & 42.81 & 7.0 \\
\hline 7 & 日 & 3.84 & 46.65 & 9.0 \\
\hline 8 & 日 & 4.50 & 51.15 & 9.0 \\
\hline
\end{tabular}

上記の圧力は T. 50 の坑口に取付けた日力計の読文 であるが，压入部分は压誓の位置よりる8 $\mathrm{m}$ 高くな

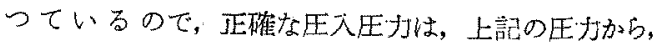
$0.8 \mathrm{~kg} / \mathrm{cm}^{2}$ を減じなければならない。王入水量は時䦎の

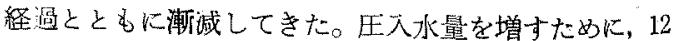




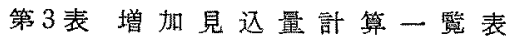

\begin{tabular}{|c|c|c|c|c|c|c|c|c|c|c|c|c|c|c|}
\hline \multirow{2}{*}{ 地，区名 } & \multirow{2}{*}{\multicolumn{2}{|c|}{$\begin{array}{c}\text { 対象面穀 } \\
\left(\mathrm{m}^{2}\right)\end{array}$}} & \multirow{2}{*}{ 㬝 } & \multicolumn{2}{|c|}{$カ^{\prime} ス \neq+y>0$} & \multirow{2}{*}{$\begin{array}{c}\text { 孔陌率 } \\
(\%)\end{array}$} & \multirow{2}{*}{ 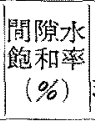 } & \multicolumn{2}{|c|}{ 残油率 $(\%)$} & \multirow{2}{*}{$\begin{array}{l}\text { 水玫 } \\
\text { 係数 } \\
(0 \%)\end{array}$} & \multirow{2}{*}{ 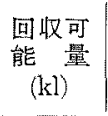 } & \multirow{2}{*}{$\begin{array}{c}\text { 一次回収 } \\
\text { 見込壆 } \\
(\mathrm{kl})\end{array}$} & \multirow{2}{*}{$\begin{array}{c}\text { 水 攻 增 } \\
(\mathrm{kl})\end{array}$} & \multirow{2}{*}{$\begin{array}{c}\text { 回 収 } \\
\text { 期 間 } \\
\text { (年) }\end{array}$} \\
\hline & & & & $\left|\begin{array}{c}\text { 面 } \\
\left(\mathrm{m}^{2}\right)\end{array}\right|$ & $\begin{array}{ll}\text { 鹰 } & \text { 厚 } \\
(\mathrm{m})\end{array}$ & & & 現 在 & 在|水攻復 & & & & & \\
\hline 墨川深 圏 & \multicolumn{14}{|c|}{ パイロットフラデイングのをめ算定せず } \\
\hline 高野 I BL & \multicolumn{2}{|r|}{63,900} & 12 & \multirow[b]{2}{*}{13,700} & -1 & \multirow{2}{*}{30.0} & 30.0 & \multirow{2}{*}{43.4} & 25.0 & 50.0 & \multicolumn{2}{|r|}{9,800} & 11,400 & 12 \\
\hline 入 樘 $\mathrm{BL}$ & \multicolumn{2}{|r|}{200,000} & 10 & & \multirow[b]{2}{*}{1} & & 30.0 & & 25.0 & \multirow{2}{*}{70.0} & 89,500 & 24,130 & 65,370 & 10 \\
\hline 雄物川IV BL & \multicolumn{2}{|r|}{114,900} & 10 & 19,000 & & $\begin{array}{l}35.0 \\
40.0\end{array}$ & 30.0 & $\begin{array}{l}43.3 \\
43.5\end{array}$ & 25.0 & & 59,500 & 19,500 & 40,500 & 10 \\
\hline$"$ III $"$ & & 104,000 & 12 & - & - & 40.0 & 30.0 & 45.0 & 24.4 & 70.0 & 72,000 & 26,900 & 45,100 & 10 \\
\hline$\|$ IIIs $" \prime$ & & 17,000 & 10 & - & - & 40.0 & 30.0 & 40.0 & 25.0 & 70.0 & 6,800 & 800 & 6,000 & 7 \\
\hline$" 1 " 1$ & & 83,000 & 8 & - & - & 40.0 & 30.0 & 42.0 & 0 & 70.0 & 21,864 & 92 & 11,772 & 7 \\
\hline $\begin{array}{l}\text { 八㢦 IV 層 } \\
\text { パロット }\end{array}$ & & ハ1口 & $7=$ & 12 & 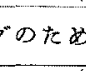 & & $\ldots-1$ & & & & & & & \\
\hline & (1) & $33,200^{\prime}$ & 7 & - & - & 30.0 & 30.0 & 45.1 & 30.0 & 70.0 & 7,369 & 49 & 5,720 & 5 \\
\hline & (2) & 11,325 & 9 & - & -1 & 42.0 & 30.0 & 51.2 & 30.0 & 60.0 & 5,350 & 250 & 5,100 & 9 \\
\hline 上小国 II 層 & |t। & 44,525 & & & & & & & & & 12,719 & & 10,820 & \\
\hline & (1) & 35,480 & 15 & - & - & 30.0 & 30.0 & 44.3 & & 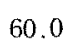 & 83 & 0 & 11,783 & 11 \\
\hline & (2) & 7,270 & 20 & - & - & 40.0 & 30.0 & 41.3 & 32.2 & 60.0 & 45 & 0 & 3,245 & 6 \\
\hline & (3) & 24,000 & 20 & - & - & 40.0 & 30.0 & 44.6 & 32.0 & 60.0 & 15 & 0 & 14,515 & 13 \\
\hline 小口 IIA 層 & (4) & 47,970 & 20 & - & - & 40.0 & & 42.4 & 32.0 & 50.0 & 20,000 & 0 & 20,000 & 16 \\
\hline & 䛨 & 114,720 & & & & & & & & & & 0 & 49,543 & \\
\hline & (1) & 34,800 & 11.5 & 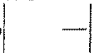 & - & .0 & & 6 & & & & & 8,275 & 9 \\
\hline 東山 B 睌 & (2) & 28,690 & 12 & - & - & 35.0 & 30.0 & 53.6 & 30.0 & 60.0 & 17,000 & 1,300 & 15,800 & 9 \\
\hline & 計 & 63,490 & & & & & & & & & & & 24,075 & \\
\hline & (1) & 42,340 & 15 & 一 & - & 35.0 & 30.0 & 43.1 & 00.4 & 00.0 & 500 & 2,800 & 14,700 & 12 \\
\hline 果山C 磨 & (2) & 176,854 & 15 & $一$ & - & 35.0 & 40.0 & 39.5 & 30.0 & 60.0 & 52,800 & 5,600 & 47,200 & 12 \\
\hline & 棓 & 219,194 & & & & & & & & & 70,300 & & 61,900 & \\
\hline & (1) & 26,720 & 5 & - & -1 & 32.0 & 40.0 & 60.0 & 30.0 & 60.0 & 7,700 & 1,520 & 6,180 & 5 \\
\hline 西山 $\mathrm{C}$ 層 & (2) & 20,700 & 5 & - & - & 32.0 & 40.0 & 59.0 & 30.0 & 60.0 & 5,800 & 100 & 5,700 & 4 \\
\hline & 計 & 47,420 & & & & & & & & & 13,500 & 1,620 & 11,880 & \\
\hline
\end{tabular}

月7日より上記の如く，王入王力をあげた所，12月 10

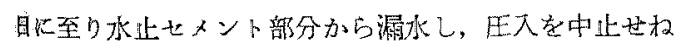
ばならなくなつた。

採取コア一試験の結果油砂の參透率は

$\begin{array}{lcc} & \begin{array}{c}\text { 平均淁透率 } \\ (\mathrm{md})\end{array} & \begin{array}{c}\text { 涴透率の筙国 } \\ (\mathrm{md})\end{array} \\ \text { T. } 49 & 98 & 65 \sim 150 \\ \text { T. } 50 & 191 & 80 \sim 295 \\ \text { T. } 51 & 155 & 28 \sim 372 \\ 3 \text { 坑平均 } & 148 & 28 \sim 372\end{array}$

T. 51 の孔隚率の值は $22.3 \sim 35.7 \%$, 平均 27.47 \%である。

T. 49, T. 50, T. 51 の 3 坑の平均含沙率は $25.56 \%$ となつている。

T. 49, T. 50, T. 51 の 3 坑の平均含水率は $73.26 \%$
となつている。

圧入水は斜坑底部の坑内水溜よりポンプにて地婊 200 石タンクに集められ，濾過槽で濾過した 5 え，斜坑副 坑, 坑口心50不タンク2基以脘水し，これを自然流下 で，T，50k圠人した。施設配置図は第 3 图に示す。

T. 52 を新掘した際のデータから、T. 50 の王入による 影䛓を調查してみると，T. 52 の坑口は T. 50 と同じ高 さで, T. 50 との距離は $76 \mathrm{~cm}$, 㑲度は約 $1930^{\circ}$ で, 深 度ば $50 \mathrm{~m}$ である。

T．50による水攻された体積の近似值は，球と棈円体 の中閒值として考光た場合 球の体積は $\left(\frac{4}{3}\right)(\pi)(5)^{3}+(2)(5)^{2}(\pi)=2,988 \mathrm{~m}^{3}$

棈円体の体積は $\left(\frac{4}{3}\right)(10)^{2}(5)(\pi)+(50)(\pi)(2)=2,404 \mathrm{~m}^{3}$ 
第 2 図 東山坑道内水攻法概念図

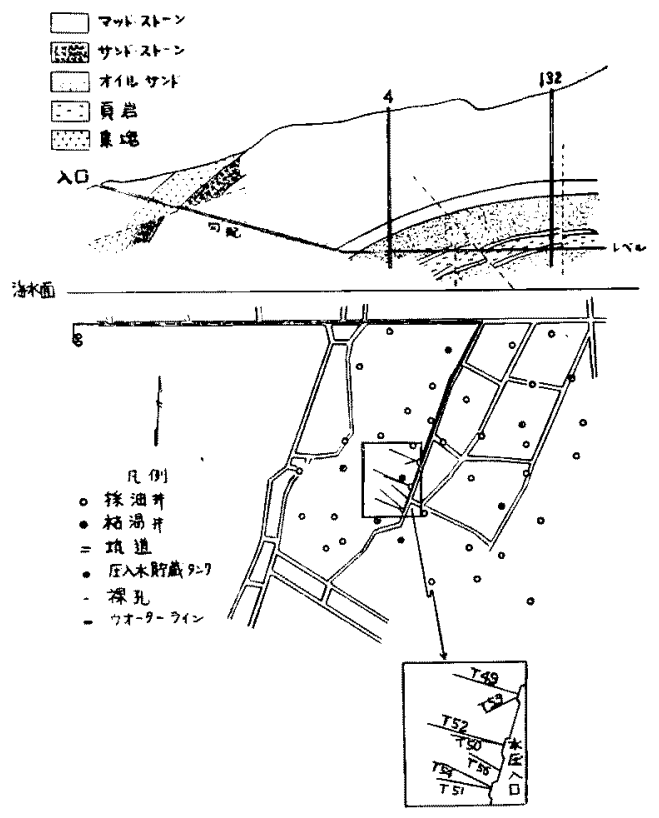

第 3 図 東山坑道王入施設図

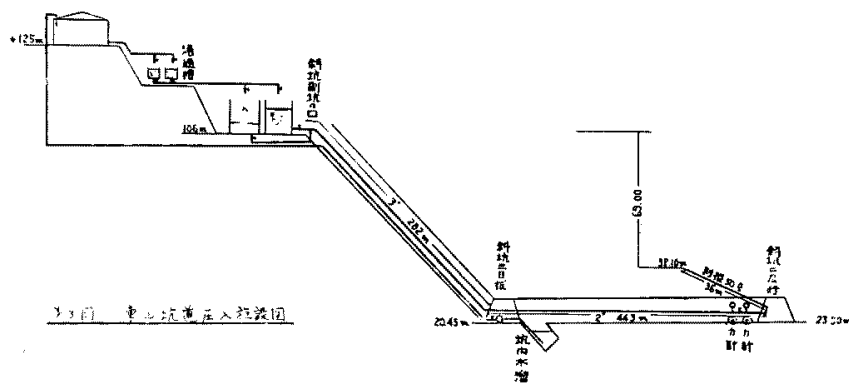

第 4 図東山坑道内水攻法経邀

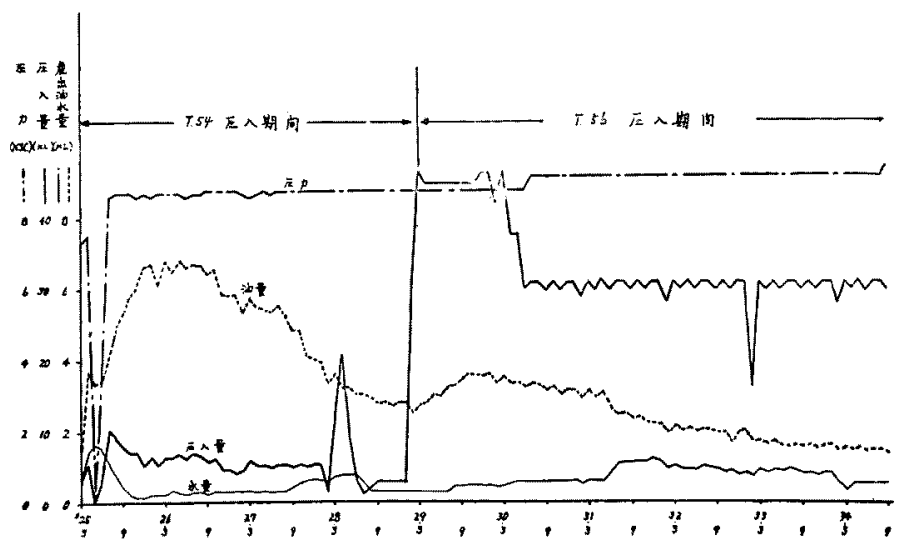

(12)
であるので， $2,600 \mathrm{~m}^{3}$ と仮定する。油砂の孔隙容積は

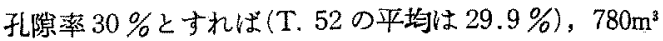

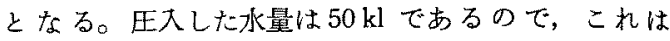
$780 \mathrm{~m}^{3}$ の $6.4 \%$ К相当する。すなわち油圈の液体孔腺 飽和率が $100 \%-6.4 \% ， つ ま り 93.6 \%$ 以下であつた ことになる。

間腙水飽和率を $40 \%$ と仮定すれば，湛砂中の油と水 の比率は $60: 40$ ，すなわち 1.5 が上限界になる。T. 52 ではコア一試験の結果によれば，25〜30 $\mathrm{m}$ の間のコア 一の油水比は平均 1.245 である。 $45 \mathrm{~m}$ 附近では 0.499 になる。これは他の部分の油水分比より高くなつてい る。このことはT，50より王大した承が油を排油する 際，奥の方向へ上りる手前の方向人，效果的に行われた ことを示している。

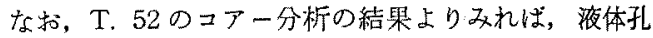

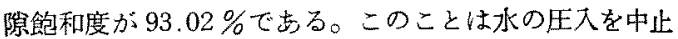
して後，王大した承が T．50の坑口から逆流したこと によると思われる。

T. 52 よりの産水の $\mathrm{Cl}^{\prime}$ 量からみると, $45 \mathrm{~m}$ 附近ま では1,500 mg/l 前後で先り, $47 \mathrm{~m}$ が $2,000 \mathrm{mg} / l$ 越 え, $50 \mathrm{~m}$ で $2,310 \mathrm{mg} / \mathrm{l}$ Kなつた。同し $50 \mathrm{~m}$ の深度で，留日測定したら 2,450 $\mathrm{mg} / l$ となつた。この事実でも水攻体程 の推定の根揓となりうる。

また，さらに前線の $\mathrm{Cl}^{\prime}$ 䟴度は大で, 圧入した附近は $\mathrm{Cl}^{\prime}$ が少ないことがい 光る。現在 T、 50 から出ている水は 284 $\mathrm{mg} / \mathrm{l}$ である。お括 T. 50 上り现入前, T. 50 より産出した水の $\mathrm{Cl}^{\prime}$ 量は 3,920 $\mathrm{mg} / l$ である。压入水の $\mathrm{Cl}^{\prime}$ 量は $50 \mathrm{mg} / \mathrm{l}$ である。

よつて, 現在 T. 52 から出ている水 の $62 \%$ \%圷入前汕層にあつた水であり， $38 \%$ が珐入した水である。T. 50 から出 ている水の $6.05 \%$ \%汪入前油層にあっ た水であり，93.95\%が生入した承とい こことなる。

以上の結果を綜合して，T．50よりの 生入は中止したが，その水攻效果は小さ い体樍であつたが確実に認められる。

\section{(2) 第 2 回目の実験}

第1回目の実験に引き続さ，斜坑二層 行，T、 54 を王入孔とし， T. 50，51, 52 を産出孔として，第 2 回目の実験㳖 計画された。 
昭和 25 年 (1950) 3 月 28 日，T、 54 に王入を閉始した が，珐入部の眇面を閉塞寸る原因となる铁の咸蝕生成物 の発生を抑 党るため，4 月 23 日压入を一たん中止し，

5月 1 日大体の解決をえたので压入を再開した。

圧入水量・比大王力・座出油水量の経過第 4 四に示 す通りである。

回取量は東山場合，一応可採油量は水攻法を実施し ない場合の約 2 倍と概算した。水攻法を実施しない時に は, 月当り $0.5 \%$ の減退率として $81 \mathrm{kl}$ 回収ができる。 水攻法の実施による增油量は，この2倍の $160 \mathrm{kl}$ と仮定 した。

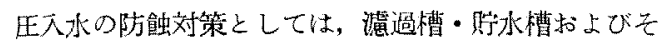
の間の鉄管は，船底防螼用酸化鉄ペイントを管装した。

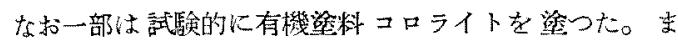
た，水江重ク口ム酸カリを加えて、鉄管内部に酸化被膜 を作り，鉄イオンが水に入るのを防ぐ方法をとつた。重 クロム酸カりの濯度は $5 \mathrm{ppm}$ を用いた。

これらの実験は T. 54 で昭和 29 年1月まで区入がつ

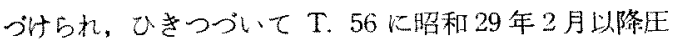
入がつつけられた。

T. 54 の王入を開始してから, 出油は月座 $7 \mathrm{kl}$ までふ 之, 生入後2年半頃上り渐减し， $3 \mathrm{kl}$ 本て減退した。 T. 56 生入してから再度堌油し，以後きわめて綬慢に 減退し，現在は $2 \mathrm{kl}$ 生産している。この実験に上る增

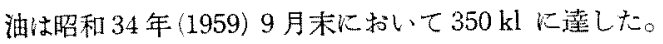
すなわち予想量の約 2.2 倍の増油実績をえた。

この実䮡とは别代昭和 30 年 5 月より坑内堅坑に水を 欧入して，油㭔内の油を坑道に採油させる試みが行われ た。广方方，生入孔として二層戻理 T. 55, 斜坑副坑 行 T. $62,63,64,65,66,67$, 斜坑副坑戻 T. 68 , 69，70，71が用いられた。圧入量は 1 日 $14 \mathrm{kl}$ であつ た。市お，斜坑副坑行と斜坑副坑戻は䄪 1 年 3 力月にて 印を中止した。

\section{3. 八橋油田}

東山坑道でおこなつた水攻法実験が好成績をおさめた ので, 次の段階として, 油田にたいするパイロットプ ロジェクトが壾画された。すなわち，油層状沉・地質・ 梁度，光の他の諸条件から判断して，わが国油出のなか で、最も水攻法の実験に適当と考光られる，八橋 III 層雄物川第 III ブロックが夷駼場所として選定され，そ の構造の中央部に O.R. 45 が開籢された。

当初の計画は OR，45を压入护として利用するつもり であつたが，油層の傾斜が $15^{\circ}$ 以上もある点から，構造 周縁部上り水の正入をする方が適当と考克，同じブロ， 東翼にある既存非 OC. 33 を改修し，水王入扑に代上 
14

げ，昭和 26 年 3 月から 1 日当り約 $50 \mathrm{kl}$ の割合で纴入を開始した。

水の王入開始後 $2 \sim 3$ 力月にして, 早

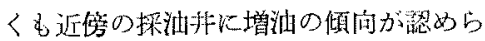
れたのでささらに增油現象をはつきり確 証するため，OC. 33 と対象の位置に压 大米 $\mathrm{OR} .46$ 孝新掘し，同年 11 月加水 の王入を開始した。これらの実験に引続 いて，フルスケールの水攻法計画がたて られた。

八橋油田で夷施された水攻法新画は， 八橋 III 層雄物川 III ブロック 八橋 III 層雄物川 IV ブロック 八橋 III 層雄物川 I ブロック 八橋 III 圈八橋 ブロッタ 八憍 III 㬝高野 I ブロック 雄物川 IIIs ブロック

八橋 III 層の地下棈造は第 5 図火示す ごとき背斜满造で，桂根層に属し，細䊀 の油砂である。探油管理上，雄物川地区 一八橋地区・高野地区に分け，さらに地 下構造から雄物川を I IV ブロックに，高野を I II ブロックにわけている。

八橋 III 圈の水攻法経過は第 6 図の通りである。

(1) 雄物川 III ブロック 本ブロックの油屬の形質は,

平均空気污透淬

平均孔擦率

有效曆厚

原油比重

原油粘度

ガス分析結果

$\mathrm{CH}_{4} 24.0 \%, \mathrm{C}_{2} \mathrm{H}_{6} 38.1 \%, \mathrm{CO}_{2} 36.0 \%$,

$\mathrm{CO} 0.1 \%, \mathrm{O}_{2} 1.1 \%$

油囦水分析結果

$\mathrm{pH} 8.0, \mathrm{Cl}^{\prime} 11,722 \mathrm{mg} / l, \mathrm{HCO}_{3}{ }^{\prime} 5,386 \mathrm{mg} / l$

当ブロ,クは昭和 11 年 (1936) 7月に開発され，以後 昭和 27 年 (1952) 5 月末 ( 2 次回収法実施時) までの III 層备坑扭の累計應油量は，次の通りである。

坑井名

OC. 10

20

24

25

26
累計産油量 現在坑底压 (kl) $\quad\left(\mathrm{kg} / \mathrm{cm}^{2}\right)$

$39,741 \quad 2.8$

7,889

464

10,529

5,530

$(2.8$

1.4

b. 6
比重 1.013

$460 \mathrm{md}$

$40 \%$

$12 \mathrm{~m}$

0.860

此 1.09
第 6 図八撟 III 層水攻法経過

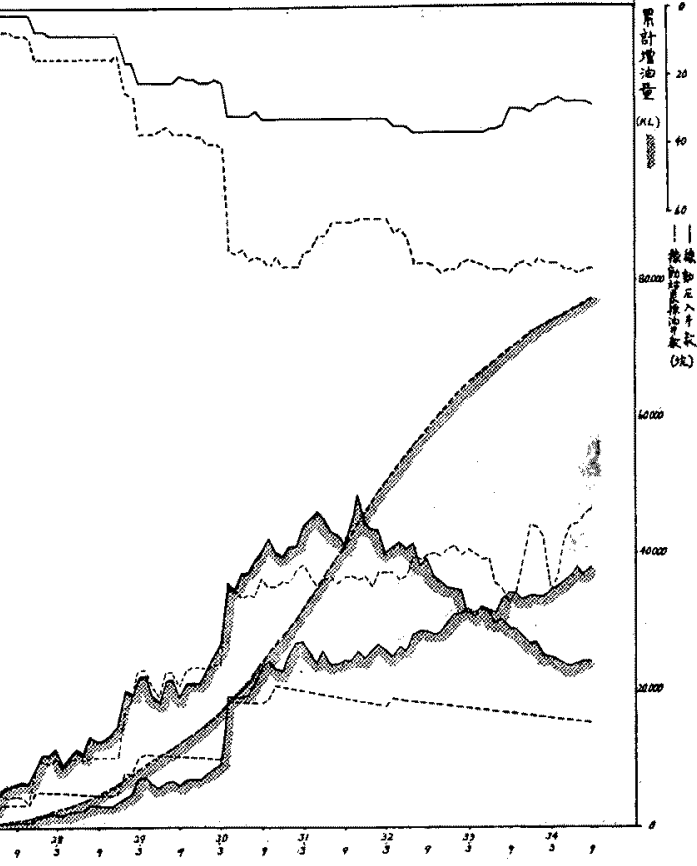

3,120

5,749

2.3

64

3,640

838

3,497

2.5

2,510

1.6

1,125

3,8

2,045

3.2

786

0 R. 5

1.0

7

45

656

0.3

合 計

88,183

水攻法対象面積として $104,000 \mathrm{~m}^{2}$ 考号, 生入非 9 坑 (深度 $230 \mathrm{~m}$ ) を東西两翼に約 $100 \sim 130 \mathrm{~m}$ の坑护間隔 で， $-210 \mathrm{~m}$ の端水線と想定されるコンターに配列儿， 水攻パターンとしては, ペリフェラールフラディングと も, あるい性 3 エーカースベーシングの変形 5 点法とも 考克られる。

計画した区、井 9 坑の内訳は, 改修 3 坑, 新崡 6 坑で 古つたが, 新挸 6 坑の 5 ち 1 坑 OR. 50 は, 予期に反し て出油したため採油挑汇編入されたので，代入井は8㧧 となつた。

対象採油非は 15 坑で，5ち1坑は新掘，7坑は改修 
[A: 入 并一筧 吂]

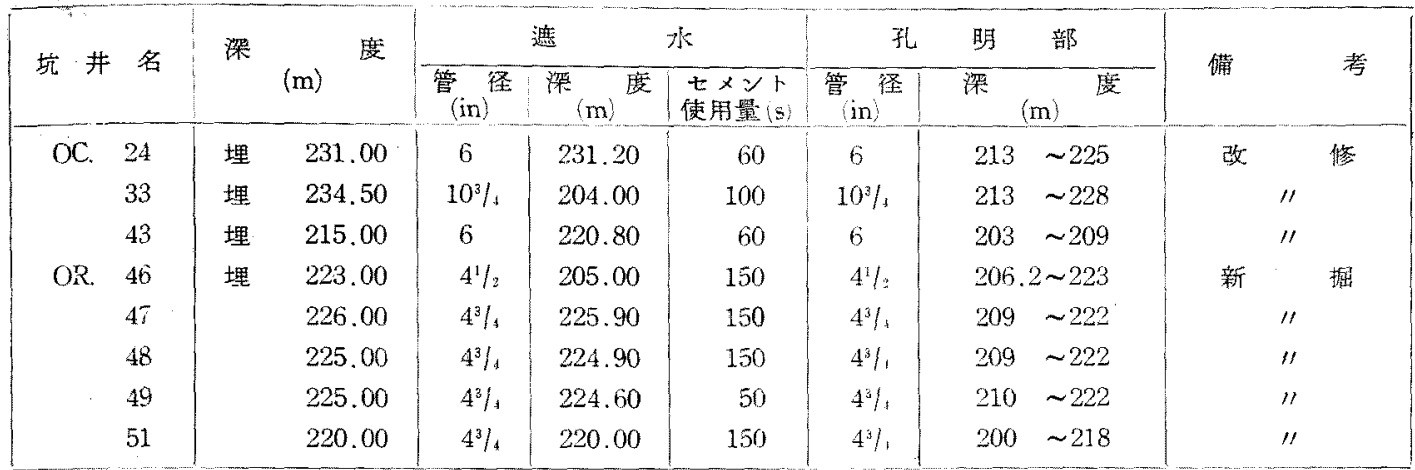

[採 油井一覽表]

\begin{tabular}{|c|c|c|c|c|c|c|c|c|c|}
\hline \multirow{2}{*}{ 竝 井 } & \multirow{2}{*}{ 知 } & \multirow{2}{*}{ 箖 } & \multirow{2}{*}{ (m) } & \multicolumn{2}{|c|}{ 遮 } & 外 & \multicolumn{2}{|c|}{ 孔 } & \multirow{2}{*}{ 荿 } \\
\hline & & & & $\begin{array}{l}\text { 管 }{ }^{\text {in }} \text { 径 } \\
\end{array}$ & (m) & 屯メント量 & $\begin{array}{c}\text { 管 烽 } \\
\text { in }\end{array}$ & 深 ${ }^{(\mathrm{m})}$ 度 & \\
\hline \multirow[t]{11}{*}{ OC. } & 10 & & 240.00 & $10^{3} \%$ & 187.89 & 止 & $8 / 8$ & $199.35 \sim 235.20$ & $!$ \\
\hline & 20 & & 273.50 & $8^{5} / 3$ & 186.34 & 11 & $6 \%$ & $184.46 \sim 262.40$ & 30.6.29 廃坑済 \\
\hline & 25 & & 226.50 & $10^{2} /$ & 189.61 & $n$ & $85 / 8$ & $191.34 \sim 224.58$ & $\vdots \ldots$ \\
\hline & 26 & & 216.00 & $4^{3} / 4$ & 200.00 & 40 & $4^{3} / 4$ & $200.00 \sim 216.00$ & 26. 改 修(㓐立) \\
\hline & 27 & 埋 & 220.00 & $4^{3} / 4$ & 202.00 & 20 & $4^{3} / 1$ & $203.00 \sim 219.00$ & 27. 改修 III GP \\
\hline & 30 & & 240.00 & $10^{3} /$. & 204.63 & 迫此 & $6^{3} / 8$ & $206.03 \sim 231.23$ & \\
\hline & 35 & 埋 & 227.00 & $4^{3} / 4$ & 208.40 & 40 & $4^{3} / 1$ & $200.30 \sim 227.00$ & 26. 改 修(埋立) \\
\hline & 50 & & 234.40 & $10^{3} / 4$ & 188.90 & 迫 此 & $6 \%$ & $178.40 \sim 231.92$ & \\
\hline & 51 & & 240.00 & $10^{3} \%$ & 190.40 & $\|$ & $6^{5} / 8$ & $192.01 \sim 238.20$ & \\
\hline & 53 & 埋 & 220,00 & $8^{5} / 8$ & 205.30 & $" 1$ & $6 \%$ & $200.00 \sim 215.00$ & | 26. 改 修(埋立) \\
\hline & 69 & & 221.00 & $4^{3} j_{1}$ & 203.00 & 35 & $4 \%$ & $203.80 \sim 221.00$ & 26: 改修(锯下) \\
\hline \multirow[t]{4}{*}{ OR } & 5 & 埋 & 225.00 & $6 / 8$ & 186.00 & & $4 y_{2}$ & $204.00 \sim 220.00$ & 27. 改修 III GP \\
\hline & 7 & 埋 & 220.00 & $8^{5} / 8$ & 362.27 & 180 & $8 \%$ & $200.00 \sim 218.00$ & 27. 改修 III GP \\
\hline & 45 & 埋 & 215.00 & $6^{5} / \mathrm{s}$ & 196.00 & 150 & $4^{3} / 4$ & $196.70 \sim 215.00$ & 25. 新 掘 \\
\hline & 50 & & 225.00 & $4^{3} / 4$ & 224.80 & 150 & $4^{3 / 4}$ & $210.00 \sim 219.00$ & 27 . 新 掘 \\
\hline
\end{tabular}

作業をおこなつた。さらに水攻法表施に障等となると考

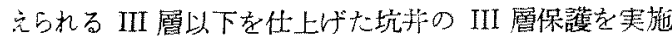
したa

\section{[證坑井ならびに油層保櫵井一䖝表]}

\begin{tabular}{|c|c|c|}
\hline 坑井名 & 深度 $(\mathrm{m})$ & 摘 \\
\hline OC. 41 & 237.80 & 昭 27 廃 坑 \\
\hline OR. 17 & $2,205.20$ & $\prime \prime 20$ \\
\hline 18 & $1,205.20$ & 1126 \\
\hline 30 埋 & 380.00 & I" 27 III 層保護 \\
\hline 1 埋 & 236.50 & $" 26 " 1$ \\
\hline 2 & 371.00 & $\|26 \quad\|$ \\
\hline 27 & 323.00 & \multirow{4}{*}{ 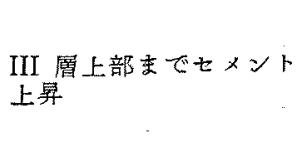 } \\
\hline 42 & 400.00 & \\
\hline 44 & 420.00 & \\
\hline 52 & 339.50 & \\
\hline
\end{tabular}

当ブロックの III 黨群は III $\mathrm{a}_{5} \mathrm{a}_{6} \mathrm{a}_{7} \mathrm{a}_{8}$ III $_{2}$ より繀

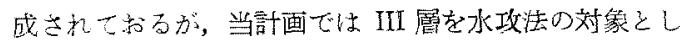
てとりまげた。 III 鹰上，上下層の連絡を遮䉼するため，

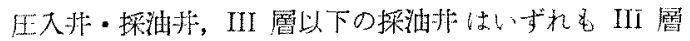

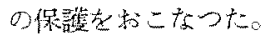

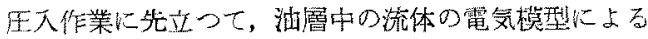
解析を行つた。この解析はとくに2次回収法に沁用し，

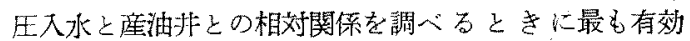
で古る。

第て図は $T_{1}, T_{2}, T_{3}, T_{4}, \cdots \cdots$ 多备㭙間比て回収され た面積 $A_{1}, A_{2}, A_{3}, A_{4}, \cdots \cdots$ 劣あらはしている。

すなかち，第1の坑排への到澾時間がかからたとき，

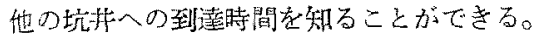

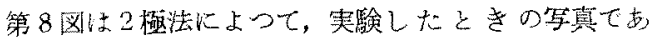
$Z_{0}$ 寒天の愿さ $7 \mathrm{~mm}$, 寒天の溜度 $15 \%, \mathrm{Zn}\left(\mathrm{NH}_{3}\right)_{4} \mathrm{Cl}_{2}$ 
第 7 図

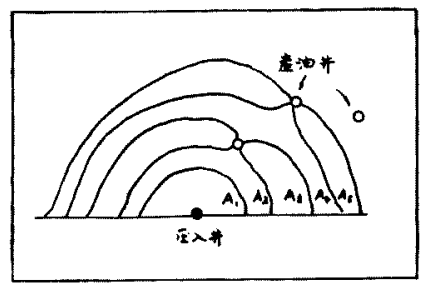

第 8 図

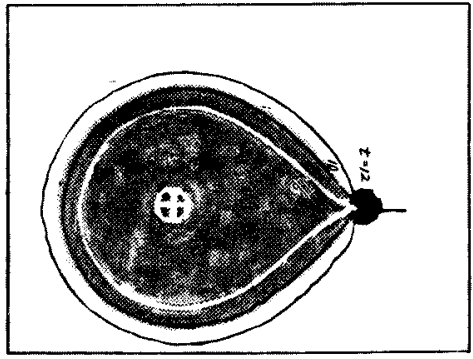

第 9 図

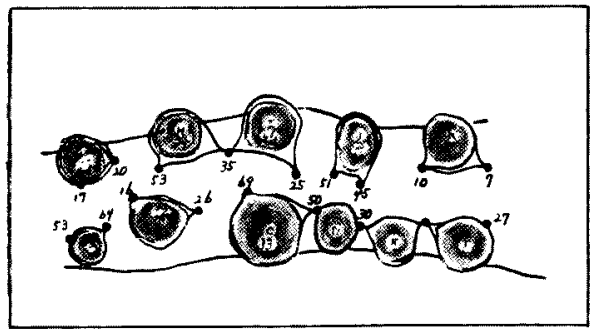

$0.5 \%$, 電流 $3 \mathrm{~mA}$, 緶尺 $1: 1$ である。

第 9 図は帝不雄物川 III ブロックに応用した場合の模 様である。ローマ字は压入北，数字は坑投番号を表放し

第 10 図雄物川水攻プラント施設配置図

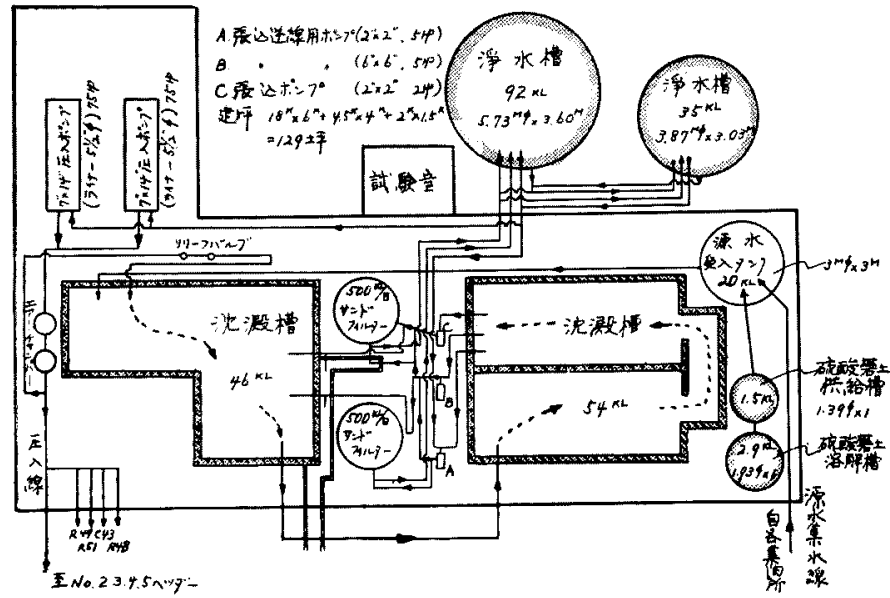

ている。

区入水源は油層内のペントナイト物賀による膨潤を防 く゚ため，油田水を用いた。集油所で水切りをした油田水 藮水線で压入プラントに集め，そこで浮游物を沈澱，

除去し，代入ポンプで压入している。坛入水㣗理プラン トの配置図は第 10 図に示す通りである。

すなわち，各集油所より集水線でプラントに集められ た水は，源水受入タンクで硫酸䄷土が添加され，さらに $100 \mathrm{kl}$ の容量を有する沈澱槽に扔くられる。ここで沈溉 された水を $500 \mathrm{kl} / \mathrm{d}$ の能打を有する急速媳過器にかけ, 浄水槽に貯水される。海水槽上り, 浄水は $7^{\prime \prime} \times 14^{\prime \prime}$ (ライナー5 $\left.1^{1}{ }^{\prime \prime}\right) 75$ PO压入ボンブで备へッダーに送 られ，一ッダーで流量計を通して，各任入非に王入され る。

当プラントの净水槽はセメント槽であるが, 他のプラ ントは鉄製タンクを用いている。

配管図は第 11 図の通りで，集水本線は $3^{\prime \prime}$ で,王入本

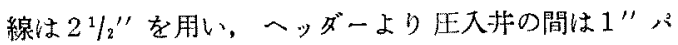
イプを用いている。

当初心配したことは，油田水中に存在する溶存酸菜に よる鹰蝕であり，この対策としては，架気との接触を絶

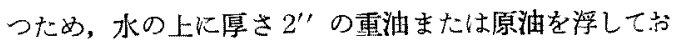
る，また鉄の表面を油田水に接触させないために，鉄管 は亜鉛メシキ，鉄槽はセメントライニングを施す等の処 踥を鹪じた。

水攻法実施経過は第 12 龱に示与通りである。昭和 26 年 (1951) 3 月，OC、33 上り压入開始，さらに同年 11 月圧入北を 2 坑に尔やした。昭和 27 年 7 月以降, 生産 量は漸增し，さらにE大井を 8 坑にし，全面的水攻法が 夷施された絈果，昭和 29 年 (1954) 1 月に生座量は $31 \mathrm{kl} / \mathrm{d}$ のピータに潗した。これは端水線に近い 第I環の坑汒の增油のためである。つ ふいて昭和 30 年 3 月に 2 度目のピーク $(27 \mathrm{k} / \mathrm{d})$ に達した。これは搆造中央部の 增油のためである。炤和 31 年 11 月のど 一ク $(19 \mathrm{kl} / \mathrm{d})$ は対象採泪扑以対するフラ クケチャリングの影製である。出氷量は 採油量の増加に伴ない急增し, 爾後漸増 している。昭和 34 年 9 月沫なでの累計 堌油量は $28,900 \mathrm{kl}$ である。

\section{（2）雄物川 IV フロック}

雄物川 III ブロックの成績にかんが み，雄物川 IV ブロックの日大計画をた てた。

当ブロックは第 5 図にみるごとく， III ブロックょり阵造の幅が広いのて, 
第 11 图磞物川 IIIプロ,ク配管因

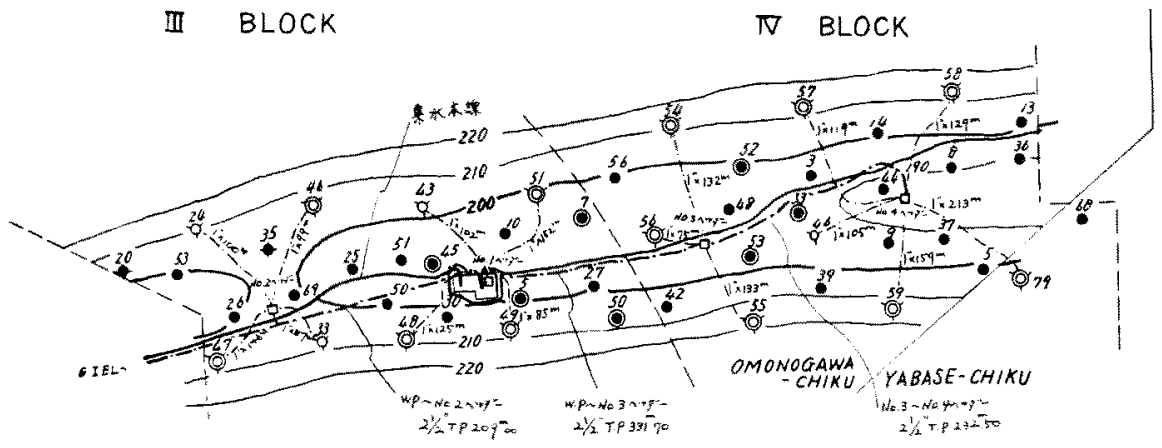

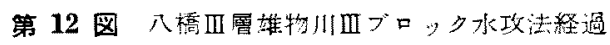

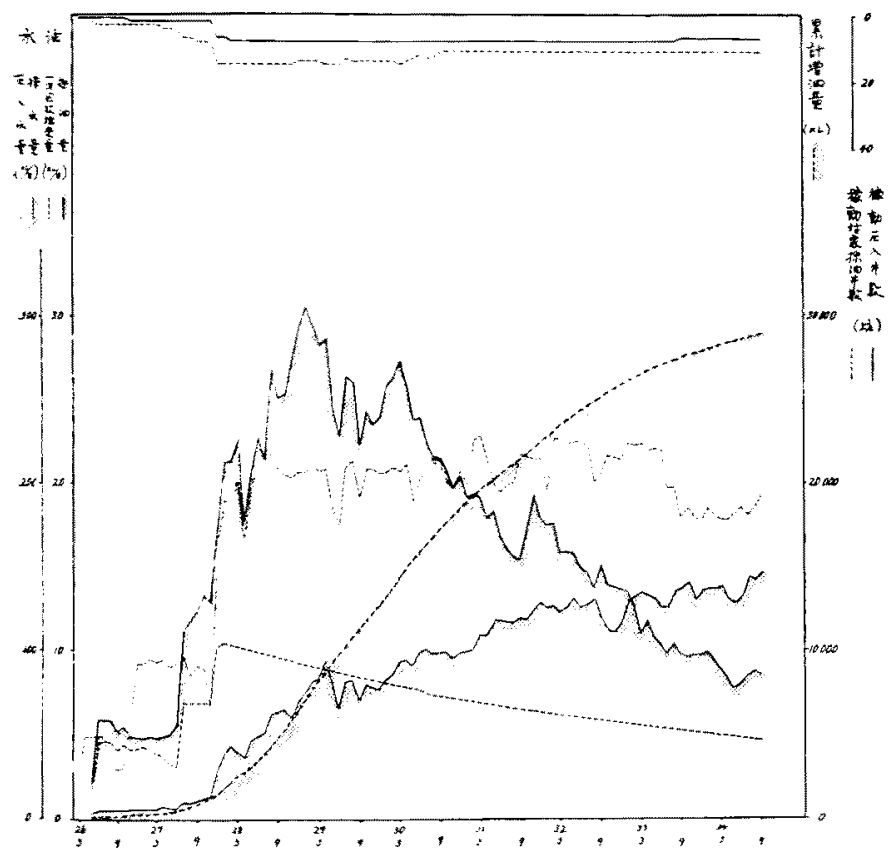

$\mathrm{CH}_{4} 24.0 \%, \mathrm{C}_{2} \mathrm{H}_{6} 38.1 \%$ $\mathrm{CO}_{2} 36.0 \%, \mathrm{CO} 0.1 \%$, $\mathrm{O}_{2} 1.1 \%$ 油画水の分析結果比重 1.013 $\mathrm{pH} 8.0, \mathrm{Cl}^{\prime} 11,722 \mathrm{mg} / \mathrm{l}$, $\mathrm{HCO}_{3}{ }^{\prime} 5,386 \mathrm{mg} / \mathrm{l}$

当ブロ,タは昭和 10 年 3 月 20 日開登 巳礼，爾来昭和 28 年 1 月末 ( 2 次回收法

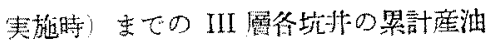
量淤通りてある。

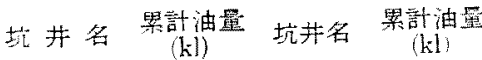

$$
\begin{aligned}
& \begin{array}{llll}
\text { OC. } 1 & 2,117 & \text { OC. } 36 & 323
\end{array} \\
& 22,001 \quad 37 \quad 8,165 \\
& \begin{array}{llll}
3 & 20,560 & 39 & 3,886
\end{array} \\
& \begin{array}{llll}
4 & 1,906 & 42 & 719
\end{array} \\
& 5 \quad 2,418 \quad 44 \quad 9,349 \\
& \begin{array}{llll}
7 & 2,536 & 46 & 1,307
\end{array} \\
& \begin{array}{llll}
8 & 10,635 & 48 & 4,716
\end{array} \\
& \begin{array}{llll}
9 & 9,259 & 56 & 3,931
\end{array} \\
& 1310,544 \quad \text { R. } 3 \quad 3,646 \\
& 14 \quad 14,381 \quad \text { YC } 11 \quad 3,648 \\
& 153,268 \quad 14 \quad 4,036 \\
& \begin{array}{llll}
28 & 11.825 & 21 & 1,167
\end{array} \\
& 29 \quad 3,049 \quad 68 \quad 9,754 \\
& 31299 \text { 合 計 } 149,450
\end{aligned}
$$

水攻法対息面䅡乙しては $114,900 \mathrm{~m}^{2}$ 老考光，当初心 ガスキャッブ面䅡は $19,000 \mathrm{~m}^{2}$ 々想定した。有效厤厚る

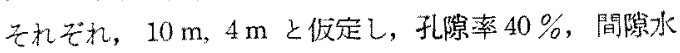

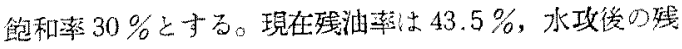
油率老 $25 \%$ をする。水攻保数を70\%と作定士ると，同

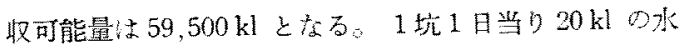

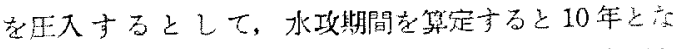
る。この閒1次彩取法て採取可能の油量法, 現日産 $8 \mathrm{kl}$, 
潞退率年当り $10 \%$ として $19,000 \mathrm{kl}$ となるので, 差 引 $40,500 \mathrm{kl}$ が 2 次回収法仁よる增油量となると想定し t。

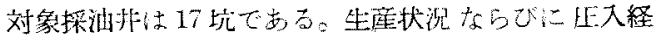

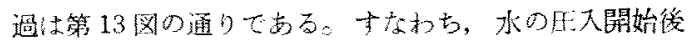

第 13 图八橋四屡雄物川IVブロック水攻法経温

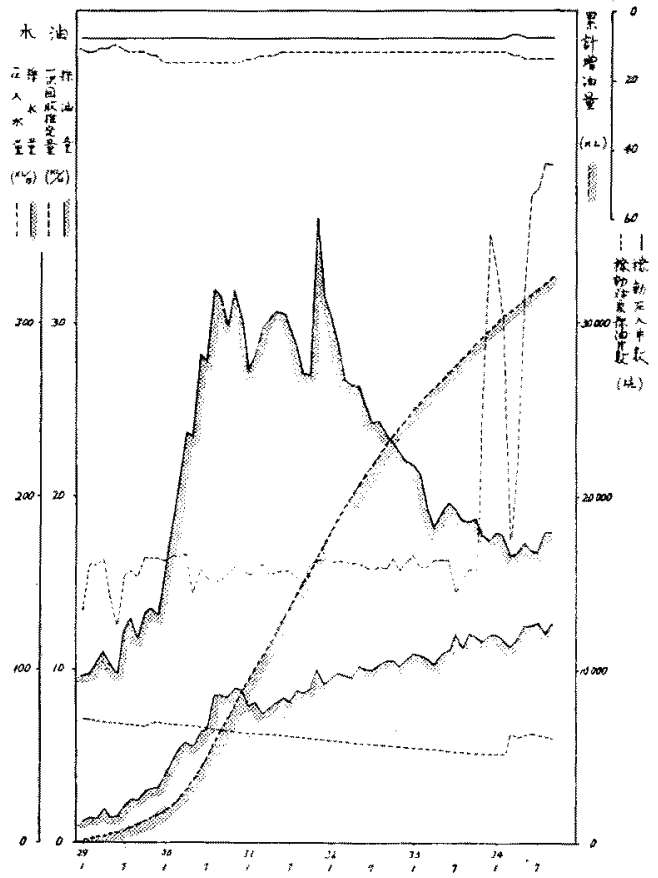

約 1 年半後の昭和 30 年 8 月, 産汕量のビータ $(32 \mathrm{kl} / \mathrm{d})$ になつた。昭和 31 年 (1956) 11 月のビーク (36 kl/d $\rangle$ 保 採油扑に実旅したフラクチャリングの影琪である。

昭和 33 年 11 月上り医入水量を增加したところ, 生産

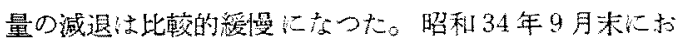
ける照新增汼量は $32,700 \mathrm{kl}$ である。

\section{(3)雄物川ブロック}

昭和 29 年 (1954) 3 月 10 日纴入非 7 坑で戍入を開始し たが，III 層の発滛が悪いためか，たいした增油を示さ なかつた。增油を示した時期は，压入開始後 1 年半老経

第 14 图八橋四筧雄物川Iプロック水攻法経過

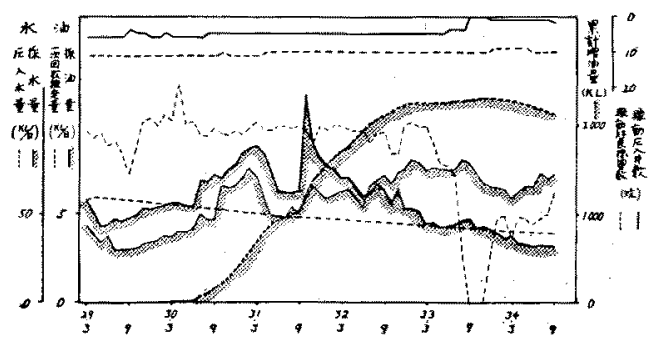

過してからである。昭和 34 年 9 月末までの瀵計增油: 量は $2,100 \mathrm{kl}$ てある。

\section{(4八畨プロック}

当ブロックは䀔和 30 年 19554 月 1 日，生入非 10 炕 より水の王入を開始しな。对象採讫排は 41 坑であるが, 採油抹の多くは III 層上IV 層の同時化上である。圧入 排はIII 層を代上げ，水の圧入をしているが、採油批は

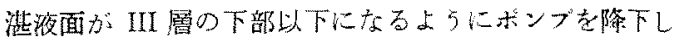

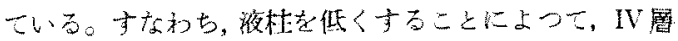
への油・水の浸入老防いている。

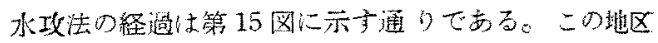

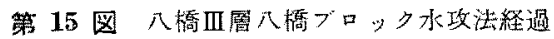

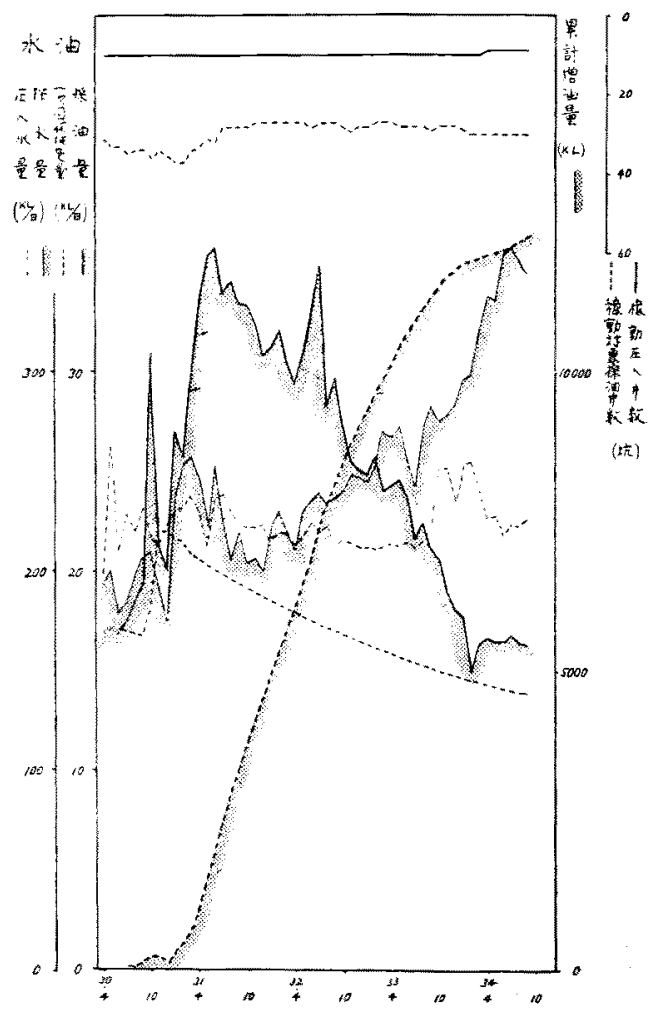

の增油は昭利 34 年 9 月末て $12.310 \mathrm{kl}$ である。增油を

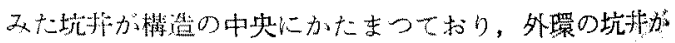
增油学及ないといらことが本地区の特靿である。

压入施設は別に当プロックにプラントを建設, 傁用し ている。プラントの旅設は第16园に示す通りである。

\section{(5)高野 Iプック}

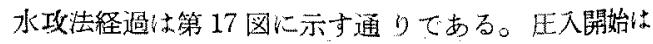
昭和 32 年 (1957) 4 月 1 日で，压入非は 4 坑である。昭 和 34 年9月来榡計增做量は $1,170 \mathrm{kl}$ である。 


\section{6)八橋 IV 層パイロット}

八穚 111 層の油層粠成岩石は砂である が，IV 層以下は㠜灰岩が主となつてい る。この凝灭岩俚対寸る水攻法学目的と して，ハイロットをこころ双た，生大斗 を2坑新掘したが，この区域のIV 層の 主要㣙層か，凝灰岩かまたは凝灭岩の上 にある砂か、不明のため，1坑は砂の部 分，他の1坑は㠜灰岩の部分を仕上げ to

眧和 32 年 (1957) 4 月 1 日过入文開始 したが、採油批にたいする影響があらう れないため，昭和 33 年 8 月に代入を中 止した。

第 17 图八橋而罾高野Iブロック水攻法経過

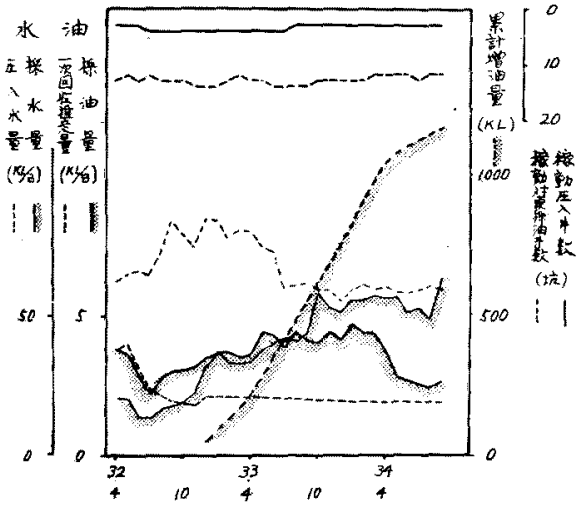

第 18 図 八橋N層バイロット地区地下ニンター

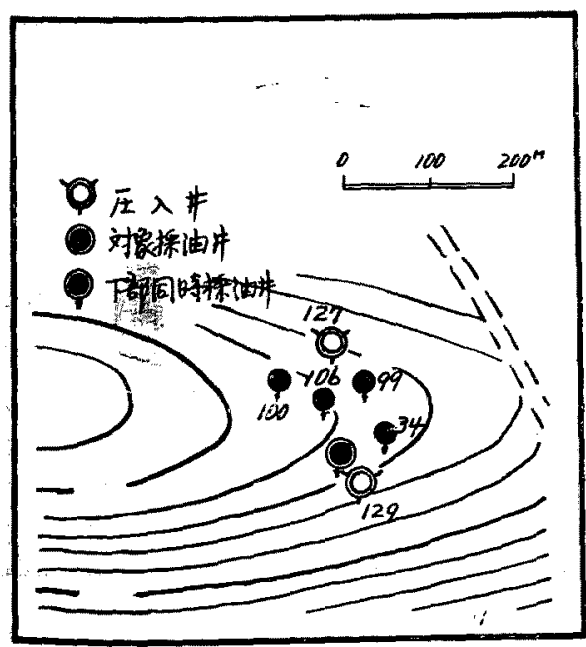

第 16 図 八槅水攻ブラント㴰設配羇図

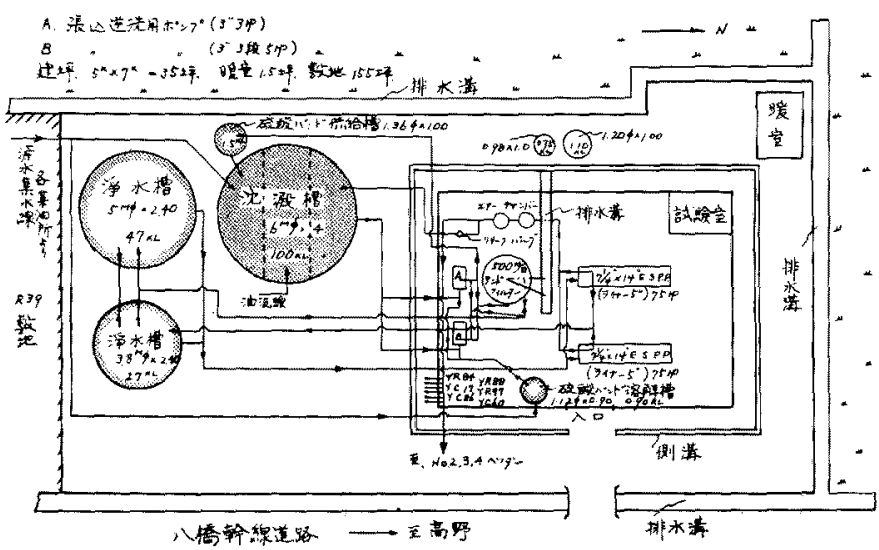

3, 黒川油田

黑川油团の深層は粗粒㠜㕄岩放よび安山岩が主要油層 である。当層は日本一の累計量を䚷る黑川 R. 5 の存在 寸る油凅である。

相当の残油量加期待されるため，当層にあらたに 3 坑

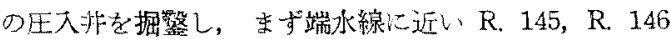
の2坑より水の圧入を試文たが，油・水量と変化好 ず，しばらく経過してから R. 144 より圧入をしたが， 依然油・水量は变化を示さなかつたので，昭和 32 年 6 月末压入号中止した。

第 19 図 黑川深層地下コンター

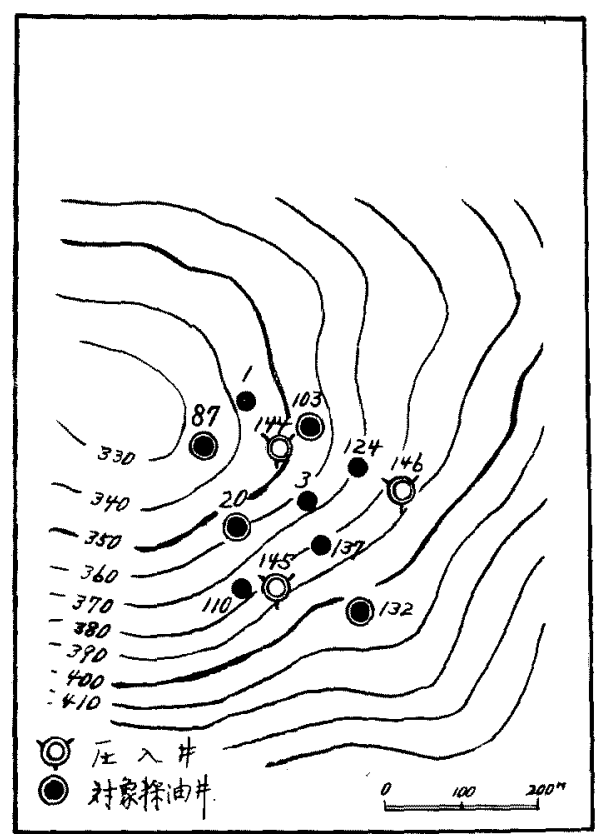




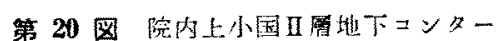

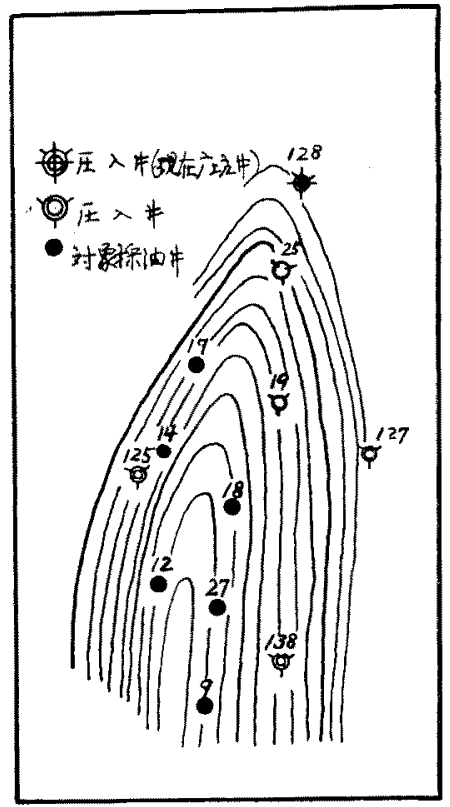

ある。しかし対學地区は端水の㣺が及でいないる として計画を立案した。油居を形成する地層は椎谷厤 で, 孔透率は $200 \mathrm{md}$, 孔腺率 $30 \%$, 有效層厚 $15 \mathrm{~m}$ て, 油の比雷は $0.6442,30^{\circ} \mathrm{C}$ におる平均粘度は $112 \mathrm{cp}$ あ。

本地区は大正2 年(1913)10月 13 日採油が開始され，以 来昭和 28 年 (1953) 1月までの紫部採油量は $122,520 \mathrm{kl}$ である。計画にさいして想定した水攻法の增油量は， $11,783 \mathrm{kl}$ である。計算根扯は次の面りである。

\begin{tabular}{|c|c|}
\hline 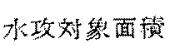 & $35,480 \mathrm{~m}^{2}$ \\
\hline 有新罢固 & $15 \mathrm{~m}$ \\
\hline 孔临浑 & $30 \%$ \\
\hline 間隙水慨和率 & $30 \%$ \\
\hline 現在残油䒚 & $44.3 \%$ \\
\hline 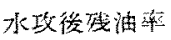 & $32 \%$ \\
\hline 水䚳僧数 & $60 \%$ \\
\hline
\end{tabular}

かくして，回収可能油量は $11,783 \mathrm{kl}$ となる。一方里 入刑 1 坑当りの1日の生入量を $20 \mathrm{kl}$ とすると，11年間

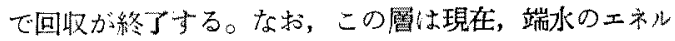
ギーが弱いため，座出していないと考えられるので，2 次回收法に上万增加見込量は回收可能油

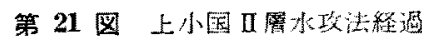

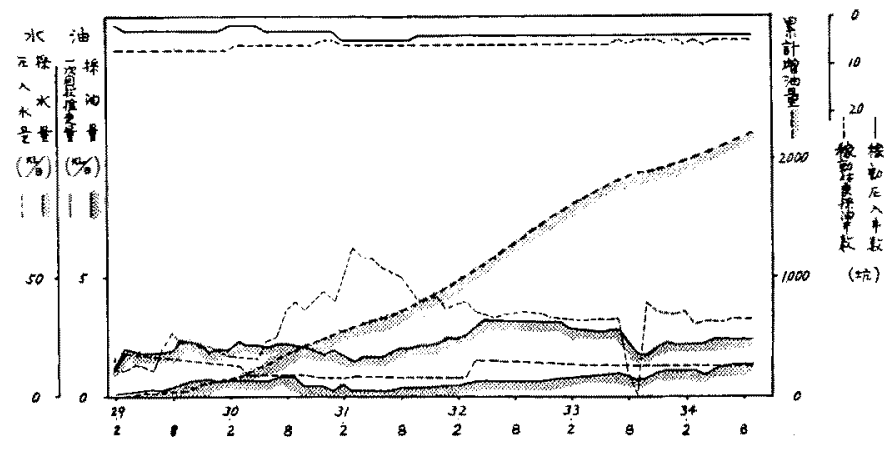

量の11,783kl となる。

な蚂当地区は 4 次放たつて計画を 拡大したので，最終的の想定增油量は $49,500 \mathrm{kl}$ になている。

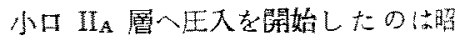
和29年5月12日で，最初2坑より玩入 したが顺次增加し，昭和 32 年6月上り 10 坑で生入を続けている。採油量は刘暴 坑护の增加に伴ないふえている。ビータ

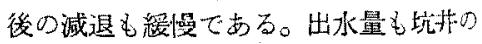

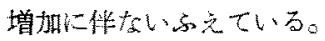

\section{4. 院内油田}

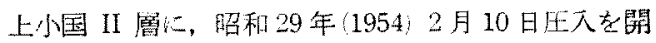

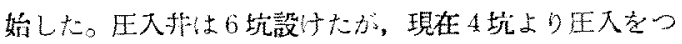

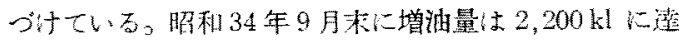
Lt:

当地区は昭租 33 年 9 月，压入を一旦中止乙て生麾状 沉の慔様をみたが，生廒量が压入中に較べて減少したの て，再度压入を奉㨢した。

\section{5. 新津油田}

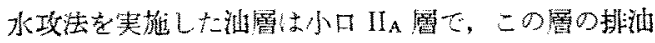
ニネルギーは，初期には洛解ガスと端水とのコンビネ一 ションであつたか，現在は $\mathrm{II}_{\mathrm{A}}$ 留企体とすると水抽しで

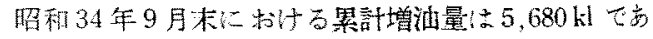
$z_{0}$

\section{6. 東山油田}

\section{(1) 東山 B 居}

当汕層は椎行層で，油时の中烘部（加平）に発達してい る。採注面䖽は $180,000 \mathrm{~m}^{2}$, 深度 $200 \sim 300 \mathrm{~m}$ で出る。 開発は明治 34 年 (1901) 4 月で, 昭和 29 年 (1954) 4 月 でに約 74,000 kl の座油量を記釾した。水攻法の対象面

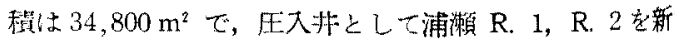

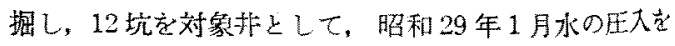

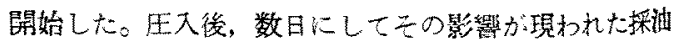

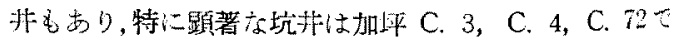

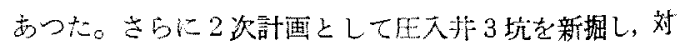


第 22 図新津小国 II層地下コンター

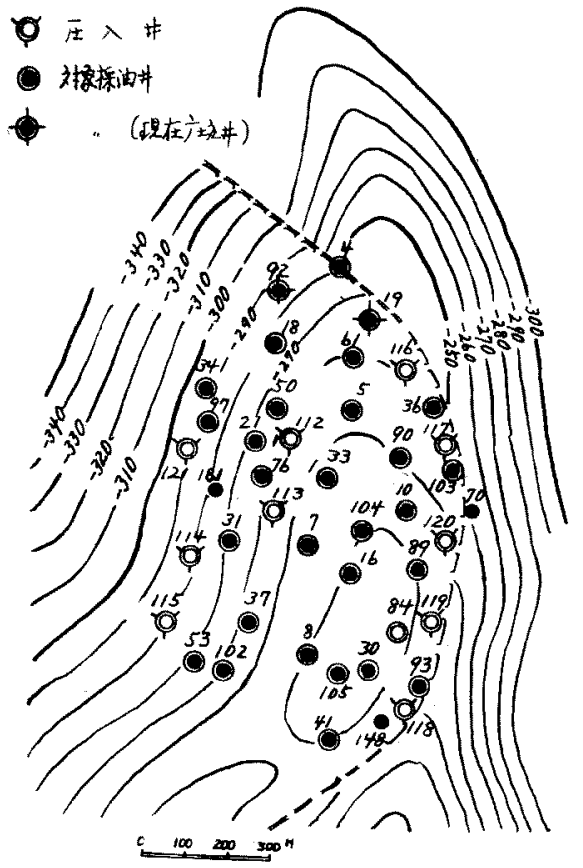

第 24 図 東山B畨地下゙コンター

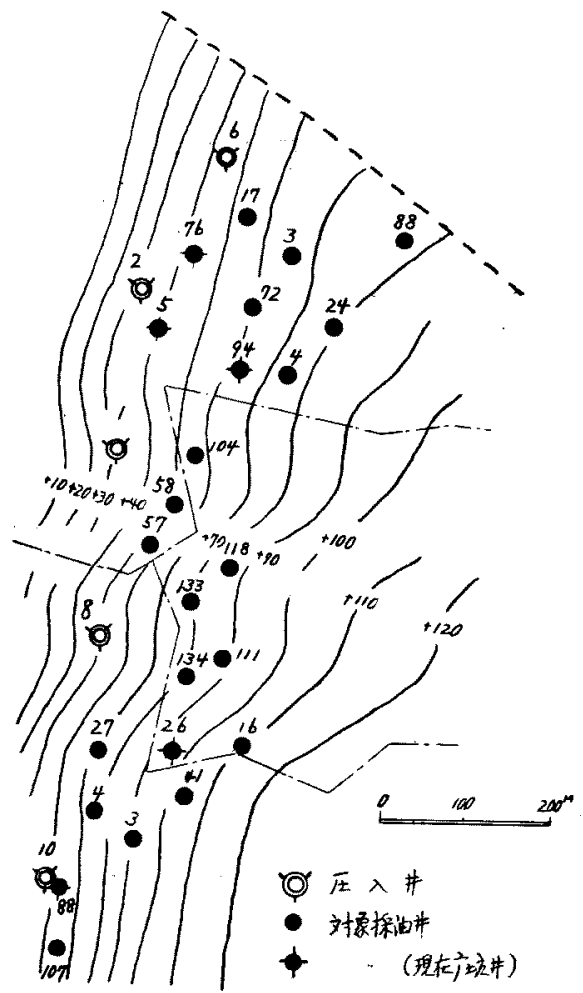

第 23 図新津 II 層水攻法経過

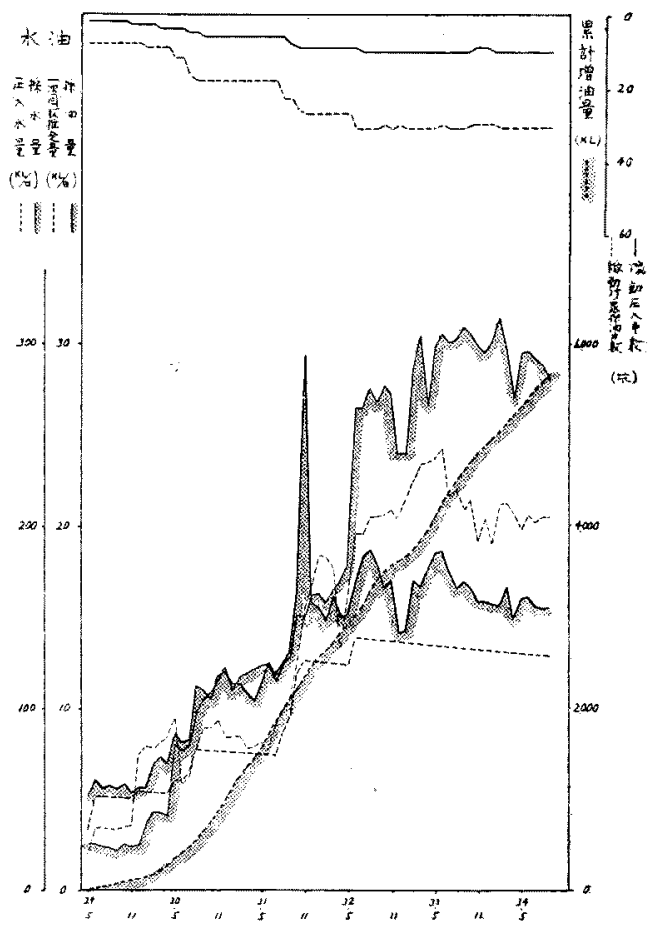

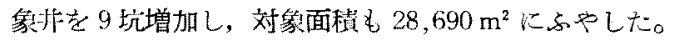
绍和 30 年 7 月, 加坪 C. 3 は最高 30 倍の增菂率を示し たが，出水量もら之，採油㠺のサンドトラブルも多くな り，2カ月後には $100 \%$ 水となつた。

增油の顕著な坑护はいずれも同様の経邀をたどつだ。 当層てはチャンネリングの問題が大きく，当初の $20 \mathrm{kl} / \mathrm{d}$. では压入レートが大きく，5〜10kl/d では水攻效果があ がらず，15 kl/d 目整に压入をつつけたが，昭和 33 年 11 月压入を一広中止 Lた。炤和 34 年 9 月末增油䁷は $2,400 \mathrm{kl}$ でる。

\section{(2) 東山 $\mathrm{C}$ 層}

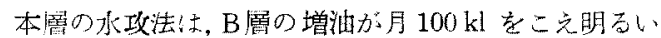
見通しの期期計画され，油層状況も B 層と大差ない电 のと判断し，いきなり本檴的水攻バーンとして5点法 がくまれ，詔和 30 年 4 月に浦瀨 R. 5 から王入が開始さ れ，順次任入师の完成とともに压入が始められた。

䀡和 30 年 8 月には 12 坑の珐入網ができあがつた。

チャンネリングの発生安尒想し，圧入レートは1坑当 り5〜7 klにした。しかし，代大效果が現われないのて， 压入レートの堌加によるテストを浦瀬 R. 20で実施した

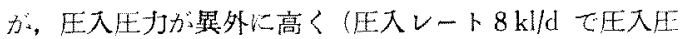
力 $\left.30 \mathrm{~kg} / \mathrm{cm}^{2}\right)$ ，一応テストを中止した。当層は增油䫘著 ならず，昭和 33 年11月王入を中纴した。 


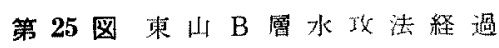

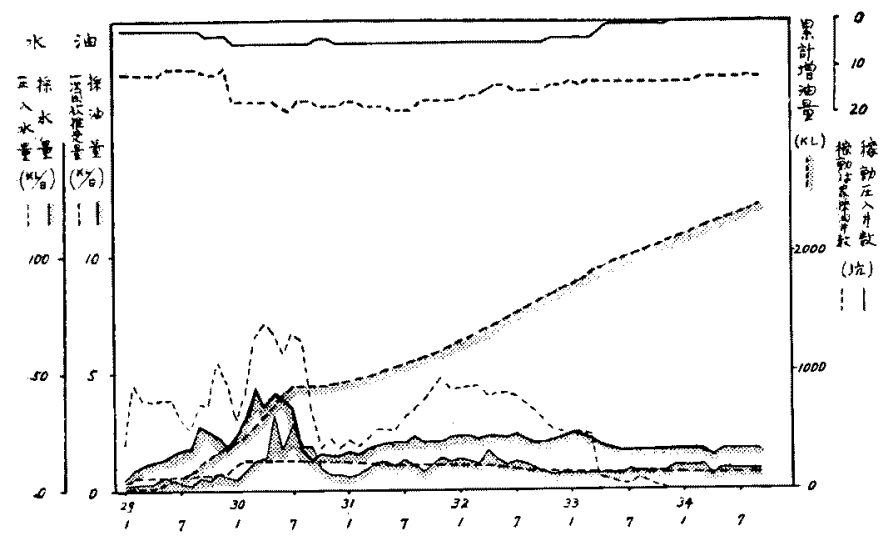

第 26 図東山C層地下ニンター

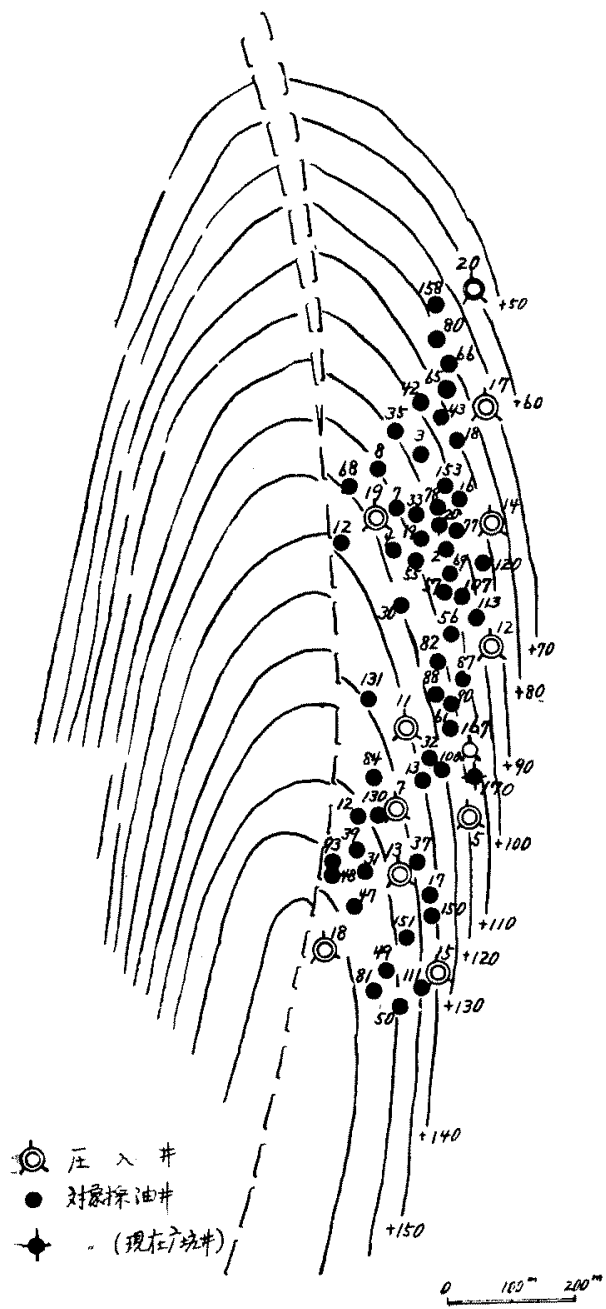

7. 西山油田

西山C㯰の水攻法の計画は昭和 29 年 初めにたてられたが，開発が古く凟料不 足のため，計画に先立つて長領 R. 60 でコアリングを実施した。対象面積を $47,420 \mathrm{~m}^{2}$, 王入井 10 坑を計画, 昭和 30 年王大を開始したが，高王のため思5上 5 に圧入できず，昭和 32 年 3 月王入を 中止した。

\section{8. 計画と実績}

各計画の増油量推定值と昭和 34 年 9 月末の実績の対比は，第 4 表に示す通り

第 27 図 東山C 層法攻法経過

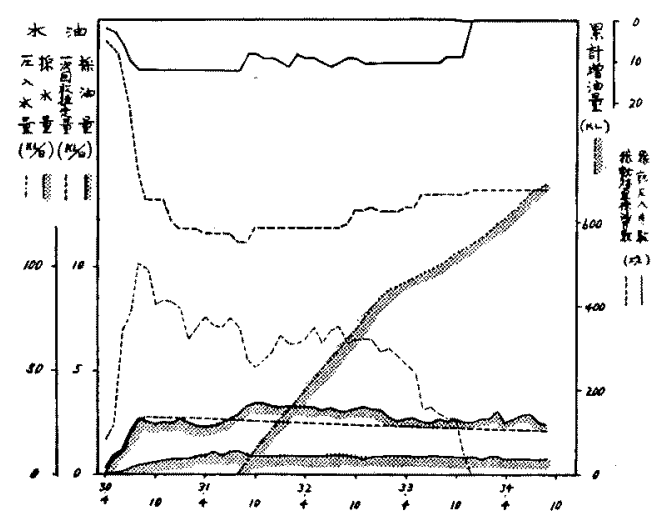

第 4 表 計画增油量と 34 年 9 月末増油実瞔の対比

\begin{tabular}{|c|c|c|c|c|}
\hline 区 & $\begin{array}{c}\text { 計画增 } \\
\text { 油畺 } \\
(\mathrm{kl})\end{array}$ & \begin{tabular}{|c|} 
計面回 \\
收期間 \\
(年)
\end{tabular} & $\begin{array}{c}\text { 害績增油量 } \\
(\mathrm{kl})\end{array}$ & $\mid$\begin{tabular}{|l} 
害續水攻 \\
期間 \\
$($ 年-月 $)$
\end{tabular} \\
\hline 野 I BL & 11,400 & 12 & $1,174.38$ & $2-6$ \\
\hline BL & 65,370 & 10 & $12,311.49$ & $4-6$ \\
\hline 雄物川 IV BL & 40,500 & 10 & $32,740,45$ & $5-9$ \\
\hline III $\quad \prime$ & 45,100 & 10 & $28,935.84$ & $8-7$ \\
\hline IIIs $" \prime$ & 6,000 & 7 & 0 & $3-4$ \\
\hline$\prime \prime$ & 11,772 & 7 & $2,123.63$ & $5-7$ \\
\hline 院内上小国II層 & 10,820 & 9 & $2,213.21$ & $5-8$ \\
\hline 新津小口 $\mathrm{II}_{\mathrm{A}}$ 層 & 49,543 & 16 & $5,678.78$ & $5-5$ \\
\hline 東 山 B 層 & 24,075 & 9 & $2,405.88$ & $5-9$ \\
\hline 東山 C 圈 & 61,900 & 12 & 697.77 & $4-6$ \\
\hline 西山 C 渭 & 11,880 & 5 & 0 & $2-0$ \\
\hline
\end{tabular}

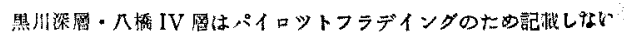


推定量と奏續值の間に相当のひらきがあるのは，回収 期間がみぢかいことも原因であるが，計画立案の際に用 いた諸数值に大きな疑問が存在することであるっこれら の諸点については、いずれ稿をあらためて発表したいと 考える。

八橋油田以外ては，新建がやや増油量が大きいという 程度であるが，代入方法等が各油層に対して適切であつ たか否かは，今後研究する余地がある。

\section{謝 辞}

本報告作成にあたり，西沼三㚚雄・小株四郎・小倉自 之・中山テル子の各氏の郝協力に謝意を表します。

\section{参考文献}

石油技術協会誌，第 18 卷，第 4 号. 帝石開発報告、第 1003 号. 帝石開発飺告，第 1005 号. 帝石開発報告，第 1013 号。 